\title{
Implementasi Reward dan Punishment Dalam Membentuk Karakter Disiplin Peserta Didik Di Madrasah Ibtidaiyah Al-Hidayah Jember
}

\author{
Siti Nur Fadilah \\ MI. Al-Hidayah Mangli \\ snurfadilahmangli@gmail.com \\ Nasirudin. F \\ MIN 3 Jember \\ nasiruddin4@gmail.com \\ DOI: $10.35719 /$ educare.v2i1.51
}

\begin{abstract}
Giving stimulus from educators in the form of giving appreciation and punishment will greatly affect the way of thinking and behavior of students in achieving the goals of character education that have been set. This study aims to describe the implementation of reward and punishment in shaping the character of students' discipline. This research uses a qualitative approach with the type of case study. Methods of data collection using interviews, observation and documentation. The validity of the data used source triangulation and technical triangulation. The results of this study indicate: (1) The implementation of rewards in shaping the discipline character of students is done by giving rewards in the form of praise and giving appreciation in the form of gifts. (2) The implementation of punishment in shaping the disciplinary character of students is carried out by giving gradual warnings, giving spontaneous warnings and written warning letters. (3) Evaluation of the implementation of rewards and punishments in shaping the character of students' discipline is using process evaluation, which is an assessment carried out during the learning process by observing the attitudes of students everyday when they are in the madrasa environment.
\end{abstract}

Keywords: Reward; Punishment; Discipline; Learners 


\begin{abstract}
Abstrak
Pemberian stimulus dari pendidik berupa pemberian apresiasi dan hukuman akan sangat mempengaruhi cara berpikir dan tingkah laku peserta didik dalam mencapai tujuan pendidikan karakter yang sudah ditetapkan. Penelitian ini bertujuan untuk mendeskripsikan implementasi reward dan punishment dalam membentuk karakter disiplin peserta didik. Penelitian ini menggunakan pendekatan kualitatif dengan jenis studi kasus. Metode pengumpulan data menggunakan wawancara, observasi dan dokumentasi. Keabsahan data menggunakan triangulasi sumber dan triangulasi tehnik. Hasil penelitian ini menunjukkan: (1) Implementasi reward dalam membentuk karakter kedisiplinan peserta didik dilakukan dengan memberikan reward dalam bentuk pujian serta memberikan apresiasi dalam bentuk hadiah. (2) Implementasi punishment dalam membentuk karakter kedisiplinan peserta didik dilakukan dengan cara memberi peringatan secara bertahap, memberi teguran spontan dan surat peringatan tertulis. (3) Evaluasi implementasi reward dan punishment dalam membentuk karakter kedisiplinan peserta didik adalah menggunakan evaluasi proses, yaitu penilaian yang dilakukan di saat proses pembelajaran berlangsung dengan mengamati dari sikap peserta didik sehari-hari ketika berada di lingkungan madrasah.
\end{abstract}

Kata Kunci: Reward; Punishment; Disiplin; Peserta Didik

\title{
PENDAHULUAN
}

Pendidikan sejatinya adalah gerbang untuk mengantar umat manusia menuju peradaban yang lebih tinggi dengan berlandaskan pada keselarasan hubungan manusia, lingkungan dan Sang Pencipta. Pendidikan adalah sebuah ranah yang di dalamnya melibatkan dialektika interpersonal dalam perjalanan umat manusia, masa lalu, masa kini, dan masa akan datang. Sehubungan dengan tujuan pendidikan sebagaimana yang dinyatakan di atas, maka pendidik dalam hal ini adalah guru mempunyai tanggung jawab untuk membimbing, mengajar, dan melatih peserta didik agar dapat secara optimal mengembangkan potensi kognitif, afektif dan psikomotorik. Dengan artian, selain guru dituntut untuk meningkatkan aspek akademis peserta didik, disisi lain guru diharapkan juga mampu membentuk sikap dan kepribadian peserta didik agar mempunyai karakter. Diantara sekian banyak 
muatan karakter yang perlu ditanamkan terhadap peserta didik, karakter kedisiplinan merupakan sesuatu yang penting untuk diprioritaskan, dimana karakter kedisiplinan dideskripsikan sebagai kesadaran dan kesediaan seseorang dalam menaati semua peraturan dan norma-norma sosial yang berlaku. ${ }^{1}$

Dalam rangka mewujudkan pembentukan karakter kedisiplinan bagi peserta didik, maka pendidikan yang ada di sekolah menjadi wadah yang strategis bagi pertumbuhan karakter peserta didik. Segala peristiwa yang terjadi di dalam sekolah dapat diintegrasikan dalam program pembentukan karakter. Pendidikan karakter merupakan usaha bersama dari seluruh warga sekolah untuk menciptakan sebuah kultur baru di sekolah, yaitu kultur pendidikan karakter. Implementasi pendidikan karakter di sekolah dikembangkan melalui pengalaman belajar yang bermuara pada pembentukan karakter dalam diri peserta didik. ${ }^{2}$ Dengan demikian, pendidikan yang sangat dibutuhkan saat ini adalah pendidikan yang dapat mengintegrasikan muatan karakter dengan pembelajaran sehingga dapat mengoptimalkan perkembangan seluruh dimensi anak (kognitif, afektif, dan psikomotorik), salah satunya yaitu dengan menerapkan alat pendidikan berupa reward dan punishment.

Reward dan punishment merupakan alat pendidikan yang strategis dan tepat untuk dijadikan alat pembelajaran. Wacana ini berangkat dari pemahaman bahwa peserta didik merupakan objek sekaligus subyek dari pendidikan, sehingga mutu pendidikan yang akan dicapai tidak terlepas dengan ketergantungan terhadap kondisi fisik, tingkah laku, dan bakat minat peserta didik. Maka, pemberian stimulus dari pendidik berupa pemberian apresiasi dan hukuman akan sangat mempengaruhi cara berpikir dan tingkah laku peserta didik dalam mencapai tujuan pendidikan karakter yang sudah

${ }^{1}$ Malayu S. P. Hasibuan, Manajemen Sumber Daya Manusia, (Jakarta: Bumi Aksara, 2004), 193.

${ }^{2}$ Doni Koesoema, Pendidikan Karakter: Strategi Mendidik Anak di Zaman Global (Jakarta: PT Gramedia, 2018), 36. 
ditetapkan. Sebagai konsekuensinya, lembaga pendidikan diharapkan mampu melakukan inovasi tentang format atau desain bentuk-bentuk alat pendidikan yang akan diberikan kepada peserta didiknya atau peserta didik, termasuk pada lembaga Madrasah Ibtidaiyah. Selain itu, karena tidak semua anak didik dapat dididik hanya dengan cara menerapkan berbagai macam peraturan yang sifatnya tertulis, maka keberadaan reward dan punishment mutlak diperlukan dalam mencapai tujuan pendidikan.

Reward secara etimologi adalah ganjaran, hadiah, penghargaan atau imbalan, sedangkan secara terminologi reward adalah suatu alat pendidikan yang diberikan ketika anak melakukan usaha yang baik atau telah mencapai sebuah tahap perkembangan tertentu sehingga anak termotivasi untuk berbuat yang lebih baik. ${ }^{3}$ Reward merupakan alat pendidikan yang mudah dilaksanakan dan sangat menyenangkan bagi peserta didik. Untuk itu reward dalam suatu proses pendidikan sangat dibutuhkan keberadaannya demi meningkatkan motivasi belajar. Maksud dari pendidik memberi reward kepada peserta didik adalah supaya peserta didik menjadi lebih giat lagi usahanya untuk memperbaiki atau mempertinggi prestasi yang akan dicapainya, dengan kata lain peserta didik menjadi lebih keras kemauannya untuk belajar lebih baik. ${ }^{4}$

Bentuk-bentuk dari penerapan reward kepada peserta didik dalam pembelajaran sebagai berikut: 1) Pujian, Pujian adalah bentuk reinforcement yang positif dan sekaligus merupakan motivasi yang baik. Pujian diberikan sebagai salah satu cara dalam merespon prestasi yang telah dilakukan oleh seseorang. Pemberian pujian kepada seseorang harus diberikan dengan tepat guna memberikan suasana yang dapat menambah gairah seseorang dalam beraktivitas. 2) Hadiah. Hadiah merupakan bentuk pemberian motivasi dan sebagai penghargaan atas perilaku baik seseorang. Pemberian hadiah ini

${ }^{3}$ Moh. Zaiful Rosyid dkk, Reward dan Punishmen, 13

${ }^{4}$ Ngalim Purwanto, Ilmu Pendidikan teoritas dan Praktis, (Bandung: Remaja Rosdakarya, 2011), 175. 
bertujuan untuk memberikan reinforcement (penguatan) terhadap perilaku yang baik. 3) Penghormatan. Penghormatan dalam hal ini diberikan kepada seseorang atas prestasinya berupa penobatan yang diumumkan dalam forum khusus. Selain itu, penghormatan juga dilakukan dengan memberikan tempat khusus baik berupa pangkat atau jabatan kepada orang tersebut. ${ }^{5}$

Sedangkan punishment menurut Moh Zainul Rosyid adalah suatu perbuatan yang dilakukan secara sadar dan sengaja yang menyebabkan penderitaan terhadap seseorang yang menerima hukuman sebagai akibat dari kesalahan yang diperbuat. Dimana di dalam dunia pendidikan, punishment termasuk dalam alat pendidikan represif yang disebut juga alat pendidikan kuratif atau koreksi. ${ }^{6}$ Abu Ahmadi menyatakan bahwa hukuman atau yang sering disebut sebagai punishment adalah tindakan yang dijatuhkan kepada anak secara sadar dan sengaja sehingga menimbulkan nestapa, agar anak akan menjadi sadar akan perbuatannya dan berjanji didalam hatinya untuk tidak mengulanginya. ${ }^{7}$

Sehubungan dengan punishment (hukuman edukatif), dapat ditemukan dalam al-Qur'an yang dapat dijadikan dasar diberlakukannya hukuman yang bersifat mendidik. Sebagaimana yang disebutkan dalam Surat Al-Zalzalah ayat 8:



Artinya: "dan barang siapa yang mengerjakan kejahatan sebesar dzarrahpun, niscaya dia akan melihat (balasan)nya pula”.

Selain itu, pentingnya diterapkan punishment juga disebutkan dalam Al-Qur'an surat Al-Isra ayat 7:

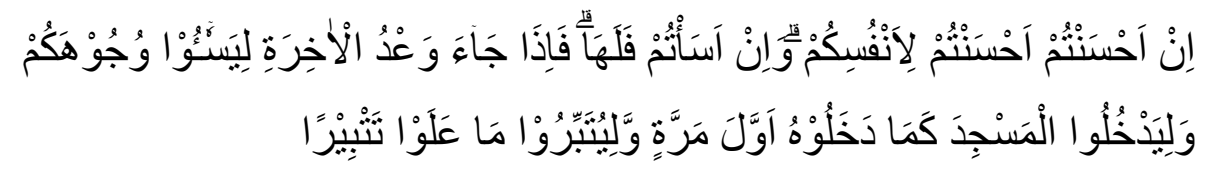

${ }^{5}$ Moh. Zainul Rosid dan Ulfatur Rahmah, Reward dan Punishmen, 18

${ }^{6}$ Moh. Zaiful Rasyid dkk, Reward dan Punishment: Konsep dan Impilikasi Keluarga, Sekolah, Pesantren, Perusahaan dan Masyarakat, 45

${ }^{7}$ Abu Ahmadi, Ilmu Pendidikan, (Jakarta Rineka Cipta, 1991), 152-153. 
Artinya: Jika kamu berbuat baik (berarti) kamu berbuat baik bagi dirimu sendiri dan jika kamu berbuat jahat, Maka (kejahatan) itu bagi dirimu sendiri, dan apabila datang saat hukuman bagi (kejahatan) yang kedua, (kami datangkan orang-orang lain) untuk menyuramkan muka-muka kamu dan mereka masuk ke dalam masjid, sebagaimana musuh-musuhmu memasukinya pada kali pertama dan untuk membinasakan sehabis-habisnya apa saja yang mereka kuasai.

Ayat-ayat di atas secara implisit menjelaskan pentingnya menerapkan hukuman dalam rangka memperbaiki tingkah laku seseorang, dengan catatan penerapan hukuman tidak diberlakukan kepada semua individu, melainkan khusus kepada mereka yang melakukan pelanggaranpelanggaran. Pelanggaran yang dimaksud adalah perbuatan atau tingkah laku yang tidak sesuai dengan tata nilai yang diberlakukan dalam lingkungan hidupnya.

Adapun hal yang sudah diterapkan di Madrasah Ibtidaiyah AlHidayah Mangli Jember, dimana lembaga tersebut menerapkan reward dan punishment yang menjadi alat pendidikan yang efektif dalam membentuk karakter peserta didik menjadi disiplin. Penerapan reward dan punishment sengaja dilakukan karena lembaga pendidikan ingin agar peserta didiknya memiliki sikap yang berkomitmen, baik dalam menghargai waktu, menaati segala peraturan, dan memiliki etika yang baik kepada orang tua, guru dan lingkungan masyarakat.

Hal ini sesuai dengan visi dan misi Madrasah Ibtidaiyah Al-Hidayah Mangli Jember yaitu terbentuknya peserta didik yang mempunyai sikap akhlakul karimah serta penanaman kedisiplinan yang diterapkan di lembaga tersebut adalah dengan mengajarkan kebiasaan-kebiasaan yang baik kepada peserta didik. Di lain sisi, penerapan reward dan punishment dipicu adanya beberapa anak memiliki sikap yang kurang memiliki komitmen dalam menghargai waktu, kurang menaati segala peraturan sekolah, dan kurang memiliki etika yang baik kepada orang tua dan guru. Diketahui ada sikap anak tidak mampu mengerjakan tugas pekerjaan rumah dengan baik, sering 
membuat kegaduhan dalam kelas, sering bermain mengajak teman sebayanya keluar dari lingkungan sekolah, dan bersikap menantang perintah guru. ${ }^{8}$ Dari alasan tersebut, maka peneliti mempunyai ketertarikan dengan mengangkat judul penelitian yaitu "Implementasi Reward dan Punishment dalam Membentuk Karakter Disiplin Peserta didik di Madrasah Ibtidaiyah Al-Hidayah Jember.

\section{METODE PENELITIAN}

Pendekatan penelitian ini menggunakan pendekatan kualitatif dan jenis penelitian studi kasus, karena penelitian bertujuan mendeskripsikan implementasi reward dan punishment dalam membentuk karakter disiplin peserta didik. Teknik pengumpulan data yang digunakan meliputi wawancara, observasi, dan dokumenter. Tahapan analisis data yang dipilih adalah teknik analisis data kualitatif model interaktif Miles, Huberman, dan Saldana. Komponen dalam analisis interaktif ini terdiri atas koleksi data (data collection), kondensasi data (data condensation), penyajian data (data display), dan penarikan kesimpulan (conclusions drawing). Keabsahan data dilakukan dengan cara mencermati data yang diperoleh dari beberapa sudut pandang yang dikenal dengan triangulasi. Penelitian ini menggunakan triangulasi sumber dan triangulasi tehnik.

\section{HASIL DAN PEMBAHASAN TEMUAN}

\section{Implementasi Reward Dalam Membentuk Karakter Disiplin Peserta didik Di Madrasah Ibtidaiyah Al-Hidayah Jember}

Implementasi reward dalam membentuk karakter disiplin peserta didik di Madrasah Ibtidaiyah Al-Hidayah Mangli Jember dilakukan dengan memberikan reward dalam bentuk berupa pujian yaitu memberikan dorongan dan perhatian kepada peserta didik apabila peserta didik yang bersangkutan dapat memberi contoh yang baik dan mampu menaati peraturan madrasah, serta memberikan apresiasi dalam bentuk hadiah.

\footnotetext{
${ }^{8}$ Observasi, MI Al Hidayah Mangli Jember 03 Januari 2020
} 
Pemberian reward diharapkan dapat membangun suatu hubungan yang positif antara guru dan peserta didik, karena pada hakikatnya pemberian hadiah adalah bagian dari pada penjelmaan dari pada rasa cinta kasih sayang seorang guru kepada peserta didik.

Temuan penelitian di atas sesuai dengan penjelasan menurut Ngalim Purwanto, bahwa reward merupakan alat pendidikan yang mudah dilaksanakan dan sangat menyenangkan bagi peserta didik. Untuk itu reward dalam suatu proses pendidikan sangat dibutuhkan keberadaannya demi meningkatkan motivasi belajar. Maksud dari pendidik memberi reward kepada peserta didik adalah supaya peserta didik menjadi lebih giat lagi usahanya untuk memperbaiki atau mempertinggi prestasi yang akan dicapainya, dengan kata lain peserta didik menjadi lebih keras kemauannya untuk belajar lebih baik. ${ }^{9}$ Adapun menurut Suharsimi Arikunto seperti dikutip Moh. Zaiful Rosid dan Ulfatur Rahmah, reward merupakan pemberian berupa sesuatu kepada individu ataupun kelompok sebagai salah satu apresiasi atau penghargaan atas pencapaian yang mereka dapatkan. ${ }^{10}$ Hal ini sesuai dengan hasil penelitian Aminatus Zakia tahun 2012 yang meneliti "Penerapan Punishment Dalam Menumbuhkan Kedisiplinan Melalui Kegiatan Ibadah Peserta didik di Madrasah Ibtidaiyah Darus Sholah Kencong Jember Tahun Pelajaran 2011/2012".11 Penelitian tersebut menghasilkan pelaksanaan pembinaan kedisiplinan peserta didik disamping memperhatikan aspek jasmani juga harus memperhatikan aspek rohani. Agar dalam pembianaan kedisiplinan itu dapat memberikan efek jera kepada peserta didik untuk tidak melanggar tata tertib sekolah.

\footnotetext{
${ }^{9}$ Ngalim Purwanto, Ilmu Pendidikan Teoritis dan Praktis (Bandung: Remaja Rosdakrya, 2000), 175.

${ }^{10}$ Moh. Zaiful Rosid dan Ulfatur Rahmah, Reward dan Punishment: Konsep dan Amplikasi Keluarga, Sekolah, Pesantren, Perusahaan, dan Masyarakat. (Malang: Literasi Nusantara, 2019), 5.

11 Aminatus Zakia (2012) Skripsi “Penerapan Punishment Dalam Menumbuhkan Kedisiplinan Melalui Kegiatan Ibadah Siswa di Madrasah Ibtidaiyah Darus Sholah Kencong Jember Tahun Pelajaran 2011/2012. (Skripsi, STAIN Jember, 2012), iv.
} 
Dalam pembinaan kedisiplinan yang dilakukan apabila peserta didik yang melanggar peraturan. Fungsi sebuah hukuman adalah membatasi perilaku menyimpang yang dilakukan para peserta didik. Namun hal tersebut dirasa kurang efektif dalam menanamkan sikap disiplin pada peserta didik. Untuk itu pihak sekolah menerapkan hukuman yang bersifat rohani yaitu dengan hukuman mempunyai nilai ibadah. Peserta didik yang melanggar peraturan kedisiplinan diberi sanksi hukuman sesuai dengan besar kesalahan yang diperbuat. Sedangkan peserta didik yang datang terlambat ke sekolah dibina untuk melakukan ibadah shalat dhuha.

Dengan demikian, jika hasil temuan data tersebut dipertemukan dengan kajian teori yang disajikan, maka dapat dikatakan bahwa keberadaan reward mempunyai peranan yang penting bagi pelaksanaan kedisplinan bagi peserta didik. Dengan memberikan penguatan berupa pujian dan hadiah mampu membangkitkan minat dan mampu mendorong seseorang untuk lebih menjaga komitmen. Motivasi akan mampu mendorong para peserta didik mempunyai kesadaran dan patuh untuk menaati semua peraturan odan norma-norma sosial yang berlaku. Terlebih jika guru memulai dari perilakunya sendiri dengan menjadikan dirinya sebagai teladan agar dapat memotivasi para peserta didik untuk mempunyai disiplin dalam melangsungkan kegiatan belajar mengajar.

\section{Implementasi Punishment dalam Membentuk Karakter Disiplin} Peserta Didik di Madrasah Ibtidaiyah Al-Hidayah Jember

Penerapan punishment dalam membentuk karakter kedisiplinan peserta didik dilakukan dengan cara memberi peringatan secara bertahap. Tahapan pertama diberikan hanya sebatas teguran spontan, jika yang bersangkutan tetap mengulangi kekeliruan yang sama sampai berkali-kali, maka akan diberikan surat peringatan tertulis yang mengarah pada peringatan yang tegas. Selain memberi teguran dan peringatan tertulis, lembaga Madrasah Ibtidaiyah juga memberikan sanksi hukuman dengan tetap mempetimbangkan kondisi psikologi peserta didik, yaitu pemberian 
punishment dilaksanakan secara berjenjang dengan menyesuaikan dengan tingkatan kelas peserta didik yang bersangkutan. Adapun bentuk-bentuk pemberian sanksi hukuman antara lain yaitu, menata dan membersihkan ruang kelas, menyapu halaman madrasah, membersihkan rumput, sampai pada membersihkan saluran air (selokan) di sebelah madrasah.

Temuan penelitian tersebut relevan dengan teori yang dikemukakan oleh Indrakusuma, dengan adanya teguran secara langsung, seorang peserta didik diharapkan menyadari bahwa apa yang telah dilakukan adalah suatu kesalahan atau sesuatu yang bertentangan dengan aturan-aturan yang ada. Namun, jika teguran tersebut belum bisa memperbaiki pelanggaran peserta didik, maka dalam hal ini, guru wajib memberikan peringatan terhadapnya. Peringatan di sini dimaksudkan agar peserta didik memperhatikan secara serius bahwa ia benar-benar telah melakukan suatu kesalahan. ${ }^{12}$ Menurut Ngalim Purwanto, setidaknya penerapan punishment harus mempunyai nilai pedagogis. Hal ini berarti, adanya hukuman yang bersifat edukatif akan menumbuhkan keinsyafan pada anak didik dari kesalahan-kesalahan yang pernah diperbuat. Hukuman diadakan karena ada pelanggaran, serta adanya kesalahan yang diperbuat. Hukuman itu sedapat-dapatnya bersifat memperbaiki, yang berarti bahwa kegiatan punishment harus mempunyai nilai mendidik (normatif) memperbaiki kelakuan dan moral anak. ${ }^{13}$ Temuan diatas juga relevan dengan penelitian oleh Ni'mah Afifah Universitas ALMA ATA Yogyakarta dalam jurnalnya yang berjudul Reward Dan Punihment bagi Pengembangan Kecerdasan Emosional Anak Usia Mi Jurnal Modeling Program Studi PGMI STIT NU Al-Hikmah. Hasil penelitiannya dapat dideskripsikan bahwa metode reward dan punishment pada anak usia sekolah (SD/MI) sangat berperan dalam meningkatkan ranah-ranah kecerdasan emosi, khususnya bagi anak usia sekolah (SD/MI) dan dalam

\footnotetext{
${ }^{12}$ Amir Daien Indrakusuma, Pengantar Ilmu Pendidikan (Surabaya: Usaha Nasional, 2001), 62 .

${ }^{13}$ M. Ngalim, Ilmu pendidikan Teoritis, 192
} 
implementasinya berdasarkan pada beberapa kode etik, seperti reward punishment tersebut harus sesuai dengan tujuan pendidikan, harus bersifat edukatif selain mempertimbangkan pada aspek usia, latar belakang serta karakter anak yang bersangkutan.

Dari uraian yang dipaparkan di atas, maka dapat disimpulkan bahwa implementasi punishment dalam hal memberikan hukuman yang bersifat mendidik mutlak untuk dilakukan sebagai upaya membentuk karakter kedisiplinan bagi peserta didik. Hukuman sebagai tindakan edukatif berupa perbuatan pendidik yang dilakukan dengan sadar pada anak didiknya atas pelanggaran yang diperbuatnya sesuai prinsip-prinsip dan nilai-nilai pendidikan. Sehingga para peserta didik sadar dan menghindari segala macam pelanggaran dan kesalahan yang tidak diinginkan atau berhati-hati dalam setiap melakukan sesuatu.

\section{Evaluasi Implementasi Reward dan Punishment dalam Membentuk Karakter Disiplin Peserta Didik di Madrasah Ibtidaiyah Al-Hidayah Jember}

Dalam pembelajaran evaluasi merupakan sebuah proses memahami, memberi arti, mendapatkan dan mengomunikasikan suatu informasi bagi keperluan pengambil keputusan, dalam hal ini keputusan terhadap apa saja yang sudah dilakukan dalam proses pembelajaran. ${ }^{14}$

Evaluasi penerapan reward dan punishment dalam membentuk karakter kedisiplinan peserta didik adalah menggunakan evaluasi proses, yaitu penilaian yang dilakukan di saat proses pembelajaran berlangsung dengan mengamati dari sikap peserta didik sehari-hari ketika berada di lingkungan madrasah.

Evaluasi pembelajaran merupakan suatu proses untuk menentukan jasa, nilai atau manfaat pembelajaran melalui kegiatan penilaian dan/atau

\footnotetext{
${ }^{14}$ Abdul Karim dan Luluk Handayani. "Pengelolaan Open and Distance Learning Di TK Muslimat NU 41 Wuluhan Jember". GENIUS: Indonesian Journal of Early Childhood Education 1, no. 1 (June 2, 2020): $30 . \quad$ https://genius.iainjember.ac.id/index.php/gns/article/view/5.
} 
pengukuran. Evaluasi pembelajaran mencakup pembuatan tentang jasa, nilai, atau manfaat program, hasil, dan proses pembelajaran. ${ }^{15}$ Menurut Wayan Nurkananda, evaluasi adalah kegiatan melakukan pemeriksaan kesesuaian antara tujuan yang telah ditetapkan dan hasil yang akan dicapai melalui kegiatan pembelajaran selama proses pembelajaran berlangsung secara bertahap dan terus menerus oleh pihak sekolah. ${ }^{16}$. Bentuk evaluasi yang digunakan yaitu evaluasi proses, dengan menilai setiap perilaku peserta didik.

Menurut E. Mulyasa, kemampuan lain yang harus dikuasai guru adalah sebagai evaluator, yaitu mampu memahami tehnik evaluasi, baik tes maupun non tes yang meliputi jenis masing-masing tehnik, karakteristik, prosedur pengembangan, serta cara menentukan baik atau tidaknya ditinjau dari berbagai segi, validitas, reliabilitas, daya beda, dan tingkat kesukaran sosial. $^{17}$

Terdapat kesesuaian antara temuan data dengan teori yang dipaparkan, yaitu guru menggunakan evaluasi proses guna mengetahui perubahan dan hasil perilaku peserta didik. Dimana guru mengamati satu persatu peserta didik yang mendapat reward dan punishment, guru juga menilai perilakuperilaku anak yang akan dinilai, seperti kedisiplinan memakai atribut lengkap sekolah, masuk kelas tepat waktu, menjaga ketenangan saat belajar di kelas, dan mengikuti kegiatan keagamaan di madrasah. Penilaian ini dilakukan setiap hari selama peserta didik berada di lingkungan sekolah.

Dengan demikian dapat diketahui bahwa guru menggunakan evaluasi proses guna mengetahui perubahan dan hasil perilaku peserta didik. Dimana guru mengamati satu persatu peserta didik yang mendapat reward dan punishment, guru juga menilai perilaku-perilaku anak yang akan dinilai,

${ }^{15}$ Dimyati dan Mujiono, Belajar dan Pembelajaran, (Jakarta: PT Asdi Mahasatya, 2002), 221.

${ }^{16}$ Wayan Nurkananda \& Sunartana, Evaluasi Pendidikan (Surabaya: Usaha Nasional, 1995), 24.

${ }^{17}$ E. Mulyasa, Menjadi Guru Profesional: Menciptakan Pembelajaran Kreatif dan Menyenangkan, (Bandung, Remaja Rosdakarya, 2011), 61. 
seperti kedisiplinan memakai atribut lengkap sekolah, masuk kelas tepat waktu, menjaga ketenangan saat belajar di kelas, dan mengikuti kegiatan keagamaan di madrasah. Penilaian ini dilakukan setiap hari selama peserta didik berada di lingkungan sekolah. Informasi-informasi yang diperoleh dari pelaksanaan evaluasi dari kegiatan ini pada gilirannya digunakan untuk memperbaiki mutu dan kualitas proses belajar mengajar kedepannya.

\section{SIMPULAN}

Berdasarkan hasil pembahasan di atas, dapat disimpulkan bahwa: (1) Implementasi reward dalam membentuk karakter kedisiplinan peserta didik di Madrasah Ibtidaiyah Al-Hidayah Mangli Jember dilakukan dengan memberikan reward berupa pujian serta memberikan apresiasi dalam bentuk hadiah. (2) Implementassi punishment dalam membentuk karakter kedisiplinan peserta didik di Madrasah Ibtidaiyah Al-Hidayah Mangli Jember dilakukan dengan cara memberi peringatan secara bertahap dan memberikan sanksi hukuman, yaitu pemberian punishment dilaksanakan secara berjenjang dengan menyesuaikan dengan tingkatan kelas peserta didik yang bersangkutan. Adapun bentuk-bentuk pemberian sanksi hukuman antara lain yaitu, menata dan membersihkan ruang kelas dan musholla, menyapu halaman madrasah, membersihkan rumput, sampai pada membersihkan saluran air (selokan) di sebelah madrasah. (3) Evaluasi implementasi reward dan punishment dalam membentuk karakter kedisiplinan peserta didik adalah menggunakan evaluasi proses, yaitu penilaian yang dilakukan disaat proses pembelajaran berlangsung dengan mengamati dari sikap peserta didik sehari-hari ketika berada di lingkungan madrasah. 


\section{DAFTAR PUSTAKA}

Abdul Karim dan Luluk Handayani. "Pengelolaan Open and Distance Learning Di TK Muslimat NU 41 Wuluhan Jember". GENIUS: Indonesian Journal of Early Childhood Education 1, no. 1 (June 2, 2020). https://genius.iain-jember.ac.id/index.php/gns/article/view/5.

Ahmadi, Abu. Ilmu Pendidikan. Jakarta Rineka Cipta, 1991.

Dimyati dan Mujiono. Belajar dan Pembelajaran. Jakarta: PT Asdi Mahasatya, 2002.

Hasibuan, Malayu S. P. Manajemen Sumber Daya Manusia. Jakarta: Bumi Aksara, 2004.

Indrakusuma, Amir Daien. Pengantar Ilmu Pendidikan. Surabaya: Usaha Nasional, 2001.

Koesoema, Doni. Pendidikan Karakter: Strategi Mendidik Anak di Zaman Global. Jakarta: PT Gramedia, 2018.

Moh. Zaiful Rosid dan Ulfatur Rahmah. Reward dan Punishment: Konsep dan Amplikasi Keluarga, Sekolah, Pesantren, Perusahaan, dan Masyarakat. Malang: Literasi Nusantara, 2019.

Mulyasa, E. Menjadi Guru Profesional: Menciptakan Pembelajaran Kreatif dan Menyenangkan. Bandung, Remaja Rosdakarya, 2011.

Observasi di Jember 03 Januari 2020.

Purwanto, Ngalim. Ilmu Pendidikan Teoritis dan Praktis. Bandung: Remaja Rosdakarya, 2011.

Wayan Nurkananda \& Sunartana. Evaluasi Pendidikan. Surabaya: Usaha Nasional, 1995.

Zakia, Aminatus. Penerapan Punishment Dalam Menumbuhkan Kedisiplinan Melalui Kegiatan Ibadah Siswa di Madrasah Ibtidaiyah Darus Sholah Kencong Jember Tahun Pelajaran 2011/2012. Skripsi-STAIN Jember, 2012. 